\title{
From Urban Homelessness to Rural Work: International Origins of the Orphan Trains
}

\author{
Mary Renck Jalongo
}

Published online: 21 September 2010

(C) Springer Science+Business Media, LLC 2010

Try to imagine, if you will-the "Age of Revolutions"-a time when political ideologies collided throughout the world. During the mid-nineteenth century, Great Britain's era of colonialism was at its apex under Queen Victoria's reign, Napoleon was in power after the French Revolution, China was in the midst of repeated rebellions, and Russian Tsar Alexander II ended serfdom to stave off an uprising. In the United States, abolitionists in the North were speaking out against slavery in the South, while in the West, the Gold Rush followed after Texas and California were annexed from Mexico. In the most powerful nations throughout the world, the Industrial Revolution was transforming societies from predominately agrarian to manufacturing, Darwin's theory of evolution was being debated, and Dickens was a popular writer.

It was against this backdrop that the story of Charles Loring Brace, a prominent social reformer, took place. In a nutshell, between 1854 and 1929, Brace and the Children's Aid Society he founded were responsible for the mass relocation of an estimated 200,000 orphaned, abandoned, and homeless children from New York City to less densely populated areas of the United States on what later became known as "the orphan trains" (National Orphan Train Complex 2010). Over the years, what Brace referred to as his "Emigration Plan" has been portrayed in film, recorded through the work of various historical societies, and highlighted in children's books. In 1978, there was a fictional mini-series, Orphan Train, starring Jill Eikenberry, Glen Close, and Kevin Dobson that dramatized this era in

M. R. Jalongo ( $\square)$

Indiana University of Pennsylvania, Indiana, PA, USA

e-mail: mjalongo@iup.edu history. The Orphan Train Heritage Society of America was founded in 1986 by Mary Ellen Johnson and a research center was established in Springdale, Arkansas. Many different state historical societies have websites devoted to orphan train information and the National Orphan Train Complex museum is housed in the restored 1917 Union Pacific Depot in Concordia, Kansas. Their web site includes historical artifacts, a national registry, a virtual tour, resources for teachers, and a calendar of orphan train rider events throughout the US. The story of "The Orphan Trains" was told in 1995, when WGBH in Boston aired a documentary on the topic for The American Experience Series, hosted by historian David McCullough (Graham and Gray 1995).

Children's literature has been another source of information about this era. Andrea Warren has written two historically accurate children's books, a chapter book called Orphan Train Rider: One Boy's True Story (1998) and a picture book, We Rode the Orphan Trains (2004), which includes interviews with eight orphan train riders. A fictional picture book by Eve Bunting (2000), Train to Somewhere, also depicts the lives of the children who were moved from urban to rural settings throughout the United States in hopes of finding a better life.

Although a few riders from the later orphan train trips in the early 1900s are still alive today, the stories of many former riders of these trains have been posted online by family members seeking to establish their family heritage. The number of You Tube videos that result from a search using the words "orphan train" is extensive, ranging from various historical society events to episodes of many popular television series. The true story that is the basis for all of these materials began in 1848 when Charles Loring Brace arrived in New York City to study theology. 


\section{New York City in the Mid-1800s}

In 1852 , over 175,000 immigrants arrived in America; by 1854 , the number rose to over 250,000 with New York being the main arrival point (www.orphantraindepot.com). Charles Loring Brace was stunned by the estimated 30,000 children who had been abandoned on doorsteps, in churches, and at hospitals (Patrick and Trickel 1997) and the large number of children working and living on the streets. Considered to be a public nuisance, children as young as 5 years of age were rounded up periodically by the police and put into prison with adult criminals (Graham and Gray 1995).

By 1852, Brace had begun working in one of the poorest sections of the city and, with missionary zeal, he decided to invest his energies in helping the children. While visiting Germany, Brace had been inspired by a residential school for homeless children outside of Hamburg called the Rauhe Haus (Rough House) that was designed to teach them a trade, such as farming, baking, tailoring, gardening, and so forth. After approximately 5 years of apprenticeship, the children were "bound in service" to people in the community. The goal of the Rauhe Haus was to give children who otherwise would not have access to education and employment opportunities for both and, of course, to provide inexpensive labor that would support industrialization. Brace wrote a book about his experiences in Germany and then returned to New York, determined to institute a program with the same governing principles and, by 1853, he had founded the Children's Aid Society (O'Connor 2001).

At the Five Points Mission, Brace began offering "Sunday Boys' Meetings" to deliver moral lectures to New York City's street children. Many of the boys were "newsies" who worked 14 hour a day on the street, earning a penny apiece (or less) for each newspaper sold. Speakers at the Sunday Boys Meetings were just as likely to be greeted by loud dissent, quick-witted remarks, or pelted with stones and garbage as to have their message wellreceived (Patrick and Trickel 1997).

An energetic reformer, Brace extended his the mission work to the project of providing housing. In 1854, the first Newsboys' Lodging House was established in a space donated by the New York Sun newspaper and, during the first year of operation, 408 boys spent an average of sixteen nights at the facility (O'Connor 2001). Next, Brace set up industrial schools where street children could learn a trade that would raise them out of the hand-to-mouth existence that most of them endured; by 1900, the Children's Aid Society (CAS) would have 25 industrial schools in and around Manhattan (O'Connor 2001). As yet another dimension of his plan to address the critical needs of the homeless children of New York, Brace created the nation's first runaway shelter.
Despite Brace's tireless fund-raising efforts and impassioned pleas, the demand for these services far outstripped the material and human resources of the CAS. An estimated 1,000 immigrants a day were flooding into New York City (Graham and Gray 1995). The oversupply of laborers resulted in few opportunities to earn the income necessary to survive, and the inadequate nutrition, tenement housing, and unsanitary conditions led to outbreaks of disease. Even much later, in 1880, 288 of every 1,000 liveborn infants in New York City died and later still in 1912, more than 1 in 10 New York children died during infancy (Fass and Mason 2000, p. 427).

When the family and kin could not provide for a child, placement in an orphanage was not a satisfactory solution either. First of all, the availability of an "orphan asylum," as they were then called, was limited. To illustrate, in 1825 , the state of New York had just four orphan asylums; by 1866, there were 60 (Holt 1992, p. 23). Even when children could be placed in an orphanage, the mortality rate was staggering-between 60 and 80 percent-with the various intestinal ailments as the most common killer (Osborne 1980).

Brace began to think that one solution might be to move the children out of the unforgiving urban environment as the Germans had done in the program he studied. He said that, "The best of all asylums for the outcast child is the farmer's home. The great duty is to get these children of unhappy fortune utterly out of their surroundings and to send them away to kind Christian homes in the country" (Graham and Gray 1995). Bolstered by an almost romanticized view of rural life, he urged the Children's Aid Society to consider a bold plan that would send children to areas where they could learn a skill, be valued as laborers, contribute to society, and [ideally, at least] be treated like members of the families with whom they were placed.

\section{An Alternative to Homelessness}

"Placing children out," as it was called, was not a new idea; the British had used it extensively as a way to populate their new territories. Circa 1617, poor children from London were transported to the American Colonies. Likewise, during the 1700s, the British turned Australia into a penal colony, sending male convicts early on and women and children later. Thus, although Brace was not the first person to consider a relocation program, he was the first to ramp it up to the scale of a major sociological experiment. His dream was that a new life in the country would be transformative for the children living in desperate circumstances in New York City.

In the mid nineteenth century, it was generally accepted that children should be put to work. Families often relied on 
children as members of the workforce and even "as late as 1880, working-class children contributed between 28 and 46 percent of household income in two-parent families" (O'Connor 2001, p. 98). "For most of our history, until the twentieth century, the social worth of children was understood primarily in terms of economic rather than emotional value.... From the earliest age when a child could hold a spinning card, she was likely engaged in household industry. By the age of twelve or so most children were treated as adult producers" (Fass and Mason 2000, p. 1). The first child labor laws in the US were not enacted until the late-1800s, and as late as 1900 , one child out of every six between the ages of ten and fifteen was gainfully employed outside the home, according to the US Census data (Fass and Mason 2000). Without question, prevailing views of childhood were fundamentally different from those today.

The kind of work children performed-in or out of the home-was determined by the race, class, and ethnic background of their families; it was also influenced by geography (Fass and Mason 2000).

Meanwhile, in mid-1800s America, areas in many states were sparsely populated. So even though children rode the orphan trains to states now considered to be Western-such as Colorado, Kansas, Nebraska, Texas, and California-they also were placed in rural New York, Connecticut, Massachusetts, New Jersey, Ohio, and Pennsylvania; Midwestern states such as Illinois, Indiana, Iowa, Michigan, Minnesota, Missouri, Wisconsin; in the Southern states, including Arkansas, Florida, Louisiana, North Carolina, South Carolina, and Virginia; and even in Canada (Cook 1995; Orphan Train Depot 2010).

\section{Implementation of the Placing Out System}

The Children's Aid Society's emigration project started with fund raising. Charles Loring Brace argued that "placing children out" was a humane alternative to the horrors of homelessness. He further contended that the re-homing urban children in rural areas was cost-effective, often citing the statistic that it cost a one-time-only fee of $\$ 20.00$ to "place out" a child, whereas incarceration cost $\$ 140$ a year. He also capitalized on the general public's fear of vagrant children, as reflected in the title of his book, The Dangerous Classes (Brace 1872), and presented relocation as a win/win solution for all of the stakeholders. Brace also called upon Jacob Riis-a Danish immigrant, newspaper reporter, author of the book How the Other Half Lives (Riis 1890), and one of the first photo journalists (Carter 2008) - to generate sympathy for the street children through prose and pictures that would raise public awareness of the children's plight and increase contributions to the Children's Aid Society.
The CAS worked to arrange and advertise the trips, hire the adult agents who would accompany the children, obtain the legal permissions needed for relocation, and identify families on the receiving end. In 1853, the first "little company"-consisting of 45 children who traveled to Dowagiac, Michigan-set out. During 1854, 66 boys and 72 girls were placed in rural Pennsylvania (Kahan 2006, pp. 55-56). From these tentative beginnings, the program grew exponentially. In year one, 207 children were placed out, and by year two, 863 children were relocated from New York to rural areas (O'Connor 2001). By 1929 when the program ended, somewhere between 100,000 and 250,000 city children had been carried by CAS train to all of the contiguous forty-eight states except Arizona (O'Connor 2001). The Orphan Train program was widely imitated. Forty thousand children were sent to Catholic communities by the Sisters of Charity while organizations in Boston, Philadelphia and Chicago relocated thousands more (Graham and Gray 1995). Inspired by Brace's success, several European nations-including England, Germany, Norway, and Sweden-instituted similar programs. In England alone, a program headed by Dr. Barnardo exported more than 80,000 English slum children throughout the Commonwealth.

Contrary to some of the Hollywood dramatizations, most of the children already had a family who was interested in fostering them. The Children's Aid Society reported that families needed the recommendation of a committee of leading citizens (i.e., pastor, justice of the peace, banker, doctor) in order to qualify for a child and that follow ups on the placements were made. Given the demand for services and flawed record keeping practices, however, it is unlikely that these stated policies were consistently followed (O'Connor 2001).

During the orphan train trip, children were accompanied by a placing agent. The trains stopped in scheduled locations and it was an event that attracted much attention in remote, rural areas. Children usually lined up in front of community members at some gathering place, such as a church, opera house, court house, or makeshift platform so that everyone could see which children were going to various families. In fact, this is the origin of the phrase being "put up for adoption" (Holt 1992). Of course, children were encouraged to look and act their best while the families tried to determine a child's value as a worker on farm or a local business. Unlike modern adoption, it was the youngest children who were more difficult to place because they would not be able to contribute as much work as an older child. Children who were not selected returned to the train to travel on to another stop and brothers and sisters often were separated as a result. The agent was responsible for explaining the CAS's rules to the assembled crowd. All placements were on a trial basis and children 
were free to leave their assignments. Children who stayed were expected to work in exchange for housing, food, and education. Children were to be treated with the same care and respect as kin; in short, "Brace's system put its faith in the kindness of strangers" (Graham and Gray 1995) and results often were mixed. This letter from archival documents of the CAS from Claretta Miller, who enclosed a photograph of herself with a calf, illustrates the complex emotions surrounding relocation:

Nobody seemed to want to keep me very long. I was shuffled from one home to another for many months until I finally was placed with the Carmens. That's me and that's my calf. I made pets out of all the calves and they just tagged me everywhere. I really had a wonderful time. They were so good to me andas far as having a wonderful family, I was one of the lucky. They were always there for me when I needed them. Always. (Graham and Gray 1995)

Although the CAS had a stated goal of visiting each child once a year, this did not occur, not only because the organization lacked the staff to make the visits but also because dissatisfied foster families sometimes sent the children elsewhere and some children left their placements. In 1883, Brace agreed to an independent investigation in response to some criticism of the CAS's work. The group concluded that the local committees had not screened foster families adequately but that the majority of children under age 14 were leading satisfactory lives (Graham and Gray 1995). What is sometimes overlooked in discussions of this era is that the families who took them in sometimes wereat least by today's standards-children themselves; life expectancy was 39 years in 1850 (Weight of the Evidence 2006). Prior to the 1860s, 10-year-old girls in the United States could "give consent" to be legally married and boys of the same age were expected to put in a full day of adultlevel labor (Jalongo and Isenberg 2012, in press).

Without a doubt, children who rode the orphan trains differed in many ways from those who populated the families who took them in. As Gish (1999) observes, "Employers and foster parents expected the young emigrants to be passive, obedient employees and foster children. Probably few children from any region of the country could have met such expectations, but the youths CAS brought to the West, toughened by life in the street of New York, certainly did not" (p. 132). Comparatively few of those who rode the trains were "orphans" in our contemporary understanding of the term. In the mid-1800s, women and children were a man's chattel—his property—so any child without a father was considered to be an orphan because the father was the breadwinner. This meant that, in post-Civil War America, the number of orphans increased exponentially. Even intact families might resort to placing their child in an orphanage if they could not afford to feed them and some would return to reclaim the child at a later time if their financial situation improved. Many children transported by the CAS were recent immigrants from other countries-particularly Ireland, Germany, and Italy-so their cultural backgrounds, ways of life, religious training, and gene pool were entirely different from those that characterized their new neighbors and communities.

\section{Evaluating Brace's Contributions}

If the criterion for success is full integration of the orphan train rider into the family, then the failure rate was high. If the criterion is an improvement over marginal existence on the streets, the successes of the CAS are more impressive. In a comprehensive statistical analysis of 280 placements made by the Children's Aid Society during its first year of operation, sociologist Bruce Bellingham (1984) concluded that about 20 percent of the children had placements that were approximating our current idea of adoption, an additional 24 percent of children stayed because they had jobs, and 56 percent of the placement agreements were broken, sometimes in a matter of days. Nearly $37 \%$ of children used the program as a temporary solution, with about $16 \%$ returning on their own to New York or to their families and $11 \%$ retrieved by a family member. Gish (1999) reports that, for the cases for which information is available, the majority of emigrants $(64.9 \%)$ remained in the West; some even continued to work with the CAS to get passage for their kin to join them. But whether the placements failed or succeeded, all of the children were part of what is now considered to be the forerunner of modern foster care. Even after Charles Loring Brace died in 1890 , his son continued with the emigration plan for nearly 40 years and other agencies in the US and in other parts of the world emulated the program (Kahan 2006).

The practice of mass relocation of city children came to a close as concepts of childhood, beliefs about child labor, and public opinion about the contributions of such programs started to shift. States on the receiving end began to question whether the big cities were simply exporting their problems to them by sending incorrigible delinquents with "bad blood" into rural settings. Beginning with Michigan in 1895, states began to pass legislation that restricted the practice of placing children out. By 1927 there were only five states-Michigan, Kansas, Iowa, Nebraska, and Texas-still accepting children through the CAS (O'Connor 2001). In 1929, at the time of the Great Depression in the US economy, the last orphan train took three children to Texas.

As Marilyn Holt (1992) concludes, "The orphan trains ceased to operate in the 1920s for a variety of reasons. Criticism of the system, a professionalization of social 
services, and a change in societal attitudes brought an end to the mass child migration, but not before thousands had been resettled in rural homes" (p. 4). Ideas about parents' responsibility for children were being challenged as well: "Whereas once upon a time people had thought little of sending their children off to live with and work for total strangers, or even make transatlantic voyages on their own, now such ventures seemed perilous, unwise, and even immoral" (O’Connor 2001, p. 224).

\section{Conclusion}

Presumably, when a charitable organization takes action, it is out of a desire to help its clients, yet a determination of whether those actions represented a stride forward often occurs much later, when subsequent generations take the long view back. Judging historical events is fraught with difficulty because there is a tendency to critique historical events in terms of contemporary sensibilities, with benefit of hindsight. When this occurs, predecessors will be seriously flawed because they were (as are we) inescapably part of a particular context. Their ways of talking about their clients will sound offensive and their ideas, somewhat simplistic when subjected to 21st Century standards.

Thus, the way in which Charles Loring Brace has been described ranges from someone who presumed to systematically dismantle families of the poor to the father of modern adoption-and all places in between. He was well aware that the steps he took were extreme and wrote, "when a child of the streets stands before you in rags, with a tear-stained face, you cannot easily forget him. And yet, you are perplexed about what to do. The human soul is difficult to interfere with. You hesitate how far you should go" (Graham and Gray 1995). One moderate view of Brace's failings and contributions comes from Gish (1999) who concluded that few of the children "fit the profile of the homeless, neglected, or abused waifs" that he portrayed in order to play on the sympathies of wealthy donors; she contends that, in many cases, families were using the orphan trains as a safety valve during an era when few social services existed. "One of Brace's most enduringand problematic-legacies to modern social services is that he made it acceptable policy to intervene in the lives of the poor on the grounds of protecting their children" (Gish 1999, p. 138). Although he set out to eradicate "hereditary pauperism" and believed that removing children from the "contaminating influence" of their families was the best course of action, what he appears to have done, much more than this, was create a unique system that families used in various ways at different times to cope with the insurmountable challenges they faced. Unlike most of his contemporaries, Brace seemed to appreciate what was good in
New York's street children-their wit, energy, determination, practicality, resourcefulness, industriousness, and unconventional code of honor (O'Connor 2001).

There is little question that Charles Loring Brace, the CAS, and the child-saving movement forever transformed ideas about where children rightly belonged. A letter written by an early Orphan Train Rider and published in the transcript of the PBS's The American Experience episode, "The Orphan Trains" (Graham and Gray 1995) poignantly captures the complexity of the decisions Brace made in his crusade to rescue the city's children:

Elkhart, Indiana

May 28th, 1865

Dear Friend:

The place where I lived I did not like. They whipped me till I was all black and blue. I told the lady I did not like to stay there, so she told me I might leave. I have a good place now. I hope you will write to me and let me know if you see any of my folks in New York. I would give one hundred worlds like this if I could see my mother.

Katie Murphy

The dilemmas identified here persist in social services unto this day, raising questions such as: Who are all the stakeholders in the process? At what point do others have the right to intervene in the life of a family? When does the situation warrant a child's removal from the family? Did the action taken improve the quality of a person's life? Who is qualified to say so? Whose version of the story gets told?

When Charles Loring Brace first began his work in New York City, children whose parents were unable to care for them were placed with "next of kin" and, failing that, in an orphan asylum. After the orphan trains, however, society began to think about adoption as a legal contract. In 1851 Massachusetts passed the first adoption statute, and over the next twenty-five years, twenty-four states passed similar laws (Presser 1972; Zainaldin 1979). Even today, "Adoption issues can never be separated from class, income, and race" (Kahan 2006, p. 70) because, in most countries, "Poor countries export children to rich ones...poor parents to better off" (Pascall 1984, p. 16).

Without question, the Orphan Train Movement had a profound effect on the population of the United States, so much so that an estimated "one in twenty-five Americans is connected to an orphan train rider" (The National Orphan Train Complex 2010). By 2000, adoption had become so prevalent that it touched six in ten Americans (Pertman 2000). Perhaps the most positive and enduring message we can take for today from Charles Loring Brace, is "his abiding belief in the capability and fundamental goodness" of children living in poverty; this is a lesson that 
"our nation dearly needs to reclaim" (O'Connor 2001, p. xvii). Ultimately, as historian David McCullough (1995) stated after reviewing hundreds of historical documents about the Orphan Trains, "One sure measure of the heart and soul of any society is how it treats its children" (Graham and Gray 1995). At the very least, Charles Loring Brace treated the children that so many others of his day completely disregarded as worthy of compassion, consideration, and opportunities to learn and work.

\section{References}

Bellingham, B. (1984). Little wanderers: A socio-historical study of the nineteenth century of child fostering and adoption reform, based on early record. Ph.D. dissertation, University of Pennsylvania.

Brace, C. L. (1872/1973). The dangerous classes of New York and twenty years' work, among them. Washington DC: National Association of Social Workers.

Bunting, E. (2000). Train to somewhere. Boston: Houghton Mifflin/ Sandpiper.

Carter, C. (2008). Writing with light: Jacob Riis's ambivalent exposures. College English, 71(2), 117-141.

Cook, J. F. (1995). A history of placing-out: The orphan trains. Child Welfare League of America, 74(1), 181-197.

Fass, P. S., \& Mason, M. A. (2000). Childhood in America. New York, NY: New York University Press.

Gish, C. (1999). Rescuing the 'waifs and strays' of the city: The western emigration program of the Children's Aid Society. Fairfax, VA: Peter N. Stearns.

Graham, J., \& Gray, E. (producers) (1995). Transcript of The Orphan Train on the PBS's The American Experience Series, WGBH Boston. Available: www.pbs.org/wgbh/amex/orphan/orphants.html.

Holt, M. (1992). The orphan trains: Placing out in America. Lincoln, NE: University of Nebraska Press.
Jalongo, M. R., \& Isenberg, J. P. (2012, in press). Chapter 2: Understanding history, ethics, and philosophy. Exploring your role in early childhood education (4th ed.). Upper Saddle River, NJ: Pearson.

Kahan, M. (2006). Put up on platforms: A history of twentieth century adoption policy in the United States. Journal of Sociology \& Social Welfare, 33(3), 51-72.

National Orphan Train Complex (2010). Concordia: A Kansas Sampler. Available: www.kansassampler.org/8wonders/history. php?id=15.

O'Connor, S. (2001). Orphan trains: The story of Charles Loring Brace and the children he saved and failed. Chicago, IL: University of Chicago Press.

Orphan Train. (1978). [Fictional mini-series starring Jill Eikenberry, Glenn Close, and Kevin Dobson]. Newark, NJ: Parade Video.

Orphan Train Depot (2010). Available: www.orphantraindepot.com.

Osborne, D. K. (1980). Early childhood education in historical perspective (2nd ed.). Atlanta, GA: Education Associates.

Pascall, G. (1984). Adoption: Perspectives in social policy. In P. Bean (Ed.), Adoption: Essays in social policy, law, and sociology (pp. 9-23). London, UK: Tavistock Publications.

Patrick, M. D., \& Trickel, E. G. (1997). Orphan trains to Missouri. Columbia, MO: University of Missouri Press.

Pertman, A. (2000). Adoption nation: How the adoption revolution is transforming America. New York, NY: Basic Books.

Presser, S. (1972). The historical background of the American law of adoption. Journal of Family Law, 11, 443-516.

Riis, J. A. (1890/1971). How the other half lives. New York, NY: Dover Publications.

Warren, A. (1998). Orphan train rider: One boy's true story. Boston, MA: Houghton Mifflin/Sandpiper.

Warren, A. (2004). We rode the orphan trains. Boston, MA: Houghton Mifflin/Sandpiper.

Weight of the Evidence (2006). Life expectancy-beyond the statistics. Available: http://weightoftheevidence.blogspot.com/... /life-expectancy-beyond-statistics.html.

Zainaldin, J. S. (1979). The emergence of a modern American family law: Child custody, adoption, and the courts, 1796-1851. Northwestern University Law Review, 79(6), 1038-1089. 